\title{
ANALISIS FAKTOR-FAKTOR YANG MEMPENGARUHI MINAT MAHASISWA DALAM MEMILIH JURUSAN
}

\author{
Ivo Selvia Agusti 1)*, Pasca Dwi Putra ${ }^{2)}$ \\ 1) Fakultas Ekonomi, Universitas Negeri Medan \\ Email: unimedivo@yahoo.co.id \\ ${ }^{2)}$ Fakultas Ekonomi, Universitas Negeri Medan \\ Email: sgacenter@gmail.com
}

\begin{abstract}
Abstrak
Penelitian ini dilaksanakan di Fakultas Ekonomi Universitas Negeri Medan. Yang menjadi populasi dari penelitian ini adalah seluruh mahasiswa Kependidikan angkatan 2014 yang berjumlah 376 orang dan mahasiswa Non-Kependidikan angkatan 2014 yang berjumlah 222 orang dan jumlah yang dijadikan sampel dalam penelitian ini adalah 89 orang yang diambil dengan teknik proporsional random sampling, berdasarkan pendapat Arikunto diambil 15\% dari jumlah populasi sehingga mahasiswa Kependidikan 56 orang dan mahasiswa Non-Kependidikan 33 orang. Alat pengumpul data yang digunakan dalam penelitian ini adalah angket faktor-faktor yang mempengaruhi minat mahasiswa dalam memilih jurusan kependidikan dan non-kependidikan. Angket ini diuji cobakan kepada 20 orang responden diluar sampel dengan menggunakan uji validitas dan uji reabilitas. Data yang dikumpulkan dianalisis dengan analisis distribusi frekuensi dan hipotesis secara parsial (Uji t) dan simultan (Uji F). Hasil penelitian menunjukkan bahwa faktor internal yang mempengaruhi minat mahasiswa memilih memilih jurusan Kependidikan $69,5 \%$, faktor eksternal yang mempengaruhi minat mahasiswa memilih memilih jurusan Kependidikan $65,6 \%$, faktor internal yang mempengaruhi minat mahasiswa memilih jurusan Non-Kependidikan 70,4\%, faktor eksternal yang mempengaruhi minat mahasiswa memilih memilih jurusan Non-Kependidikan $68,8 \%$. Dengan demikian dapat disimpulkan bahwa faktor internal lebih dominan dalam mempengaruhi minat pemilihan jurusan Kependidikan dan Non-Kependidikan dan faktor eksternal berpengaruh positif dan signifikan terhadap minat pemilihan jurusan Kependidikan dan Non-Kependidikan. Jadi faktor internal dan eksternal secara simultan berpengaruh positif dan signifikan terhadap minat pemilihan jurusan Kependidikan dan Non-Kependidikan pada Mahasiswa Fakultas Ekonomi Angkatan 2014 Universitas Negeri Medan.
\end{abstract}

Keywords: Minat, Pemilihan Jurusan, Kependidikan, Non-kependidikan. 


\section{PENDAHULUAN}

Jurusan pada Fakultas Ekonomi terdiri dari Jurusan Pendidikan Ekonomi, Jurusan Akuntansi dan Jurusan Manajemen. Jurusan Pendidikan Ekonomi terdiri dari empat Program Studi yaitu Pendidikan Ekonomi, Pendidikan Akuntansi, Pendidikan Tata Niaga serta Pendidikan Administrasi Perkantoran.

Setiap jurusan memiliki peminatpeminat tersendiri, mereka memiliki pertimbangan-pertimbangan tertentu dalam memilih jurusan. Begitu pula halnya mahasiswa yang memilih Jurusan Kependidikan dan nonKependidikan. Banyak faktor yang mempengaruhi alasan mahasiswa dalam memilih jurusan, salah satu peranan penting yang harus dimiliki adalah minat. Timbulnya minat dipengaruhi oleh faktor internal (dorongan dari dalam diri, kepribadian, emosional dan lain-lain) dan juga faktor eksternal (lingkungan masyarakat, orang tua, kampus serta teman). Hal ini sangat penting untuk menghindari terjadinya penyalahgunaan profesi dalam hal ini ada fenomena yang perlu dicermati dimana mereka yang sejak awal sudah mengambil S1 kependidikan lebih cenderung untuk tidak memilih profesi guru kecuali terpaksa serta ikutikutan memilih dari hasil data menunjukan sekitar $18 \%$ mahasiswa memilih karena terpaksa, $22 \%$ memilih dikarenakan ikut-ikutan, dan $60 \%$ memilih dikarenakan minat mereka.

\section{TINJAUAN PUSTAKA}

Minat terjadi karena adanya dorongan dari perasaan senang dan adanya perhatian terhadap suatu objek atau aktivitas, sehingga terjadi kecenderungan berbuat sesuatu terhadap objek tersebut, dan menimbulkan kepuasan yang bermanfaat bagi dirinya. Hal senada sebagaimana dikemukakan Usman (2012:27) Minat merupakan sesuatu yang menetap pada diri seseorang. Minat ini besar sekali pengaruhnya terhadap belajar sebab dengan minat seseorang akan melakukan sesuatu yang diminati, sebaliknya tanpa minat seseorang tidak mungkin melakukan sesuatu, misalnya seseorang akan menaruh minat terhadap bidang kesenian, maka ia akan berusaha untuk mengetahui lebih banyak tentang kesenian.

Menurut Khairaini (2013:137) minat mengandung unsur-unsur sebagai berikut:

1. Minat adalah suatu gejala psikologis.

2. Adanya pemusatan perhatian, perasaan dan pikiran dari subyek karena tertarik.
NIAGAWAN Vol 7 No 2 Juli 2018

3. Adanya perasaan senang terhadap obyek yang menjadi sasaran.

4. Adanya kemauan atau kecenderungan pada diri subyek untuk melakukan kegiatan guna mencapai tujuan.

Dapat disimpulkan bahwa pengertian minat adalah faktor bawaan yang dipengaruhi oleh lingkungan seeorang dalam memilih sesuatu yang dikarena obyek tersebut menarik perhatian dan menimbulkan perasaan senang sehingga cenderung kepada obyek tersebut yang menjadi sasaran pilihannya

\section{Faktor-Faktor yang Mempengaruhi Minat}

Banyak faktor yang mempengaruhi minat terhadap sesuatu, secara garis besar dapat dikelompokkan menjadi 2 (dua) yang bersumber dari dalam diri individu yang bersangkutan. Hurlock (2010:139) ada beberapa faktor yang mempengaruhi minat anak pada sekolah yaitu: “a) Pengaruh orang tua, b) Teman sebaya, c) Keberhasilan akademik, d) Pengalaman dini sekolah, e) Sikap terhadap pekerjaan, f) Hubungan guru dan murid dan g) Suasana emosional sekolah."

Vivipermata (2010:12) faktor-faktor yang mempengaruhi minat siswa/mahasiswa dalam memilih jurusan maka indikatornya:

1. Faktor Internal
a. Dorongan dari dalam diri
b. Kepribadian
c. Emosional
d. Cita-cita

\section{Faktor Eksternal}
a. Lingkungan Masyarakat
b. Lingkungan Sekolah / Kampus
c. Sarana dan Prasarana

Dapat disimpulkan bahwa faktor-faktor yang mempengaruhi minat merupakan suatu faktor yang berasal dari dirinya sendiri serta dipengaruhi faktor luar yang diperoleh melalui proses belajar yang menyebabkan individu memberi perhatian terhadap orang, benda atau aktivitas yang berpengaruh terhadap tingkah laku seseorang dalam mengerjakan suatu aktifitas.

\section{METODE PENELITIAN}

\section{Lokasi Penelitian}

Penelitian ini dilakukan di Universitas Negeri Medan, Fakultas Ekonomi. Pada mahasiswa Jurusan Kependidikan dan NonKependidikan yang beralamat di Jalan Pasar V Medan Estate, Medan, Sumatera Utara. 
Populasi dan Sampel

Tabel 1 Populasi dan Sample

\begin{tabular}{|l|c|l|c|}
\hline \multicolumn{2}{|c|}{ Mahasiswa Kependidikan } & \multicolumn{2}{c|}{$\begin{array}{c}\text { Mahasiswa non- } \\
\text { Kependidikan }\end{array}$} \\
\hline Program Studi & Jumlah & Jurusan & Jumlah \\
\hline $\begin{array}{l}\text { Pendidikan } \\
\text { Ekonomi }\end{array}$ & 105 & Manajemen & 85 \\
\hline $\begin{array}{l}\text { Pendidikan Tata } \\
\text { Niaga }\end{array}$ & 104 & Akuntansi & 137 \\
\hline $\begin{array}{l}\text { Pendidikan } \\
\text { Adm.Perkantoran }\end{array}$ & 98 & - & - \\
\hline $\begin{array}{l}\text { Pendidikan } \\
\text { Akuntansi }\end{array}$ & 69 & - & - \\
\hline Jumlah & $\mathbf{3 7 6}$ & Jumlah & $\mathbf{2 2 2}$ \\
\hline Sample 15\% & $\mathbf{5 6}$ & & $\mathbf{3 3}$ \\
\hline
\end{tabular}

Sumber: Data penelitian 2016

Teknik Pengumpulan Data

Untuk memperoleh data yang lebih akurat dalam penelitian, maka metode yang digunakan dalam penelitian ini adalah dalam penyebaran angket kuesioner kepada sampel penelitian.

\section{Instrumen Penelitian}

$\begin{array}{lr}\text { Sangat Setuju (SS) } & =\text { skor } 5 \\ \text { Setuju (S) } & =\text { skor } 4 \\ \text { Kurang Setuju (KS) = skor } 3 & \\ \text { Tidak Setuju (TS) } & =\text { skor } 2 \\ \text { Sangat Tidak Setuju (STS) } & =\text { skor } 1\end{array}$

Teknik Analisis Data

Model penelitian menggunakan multiple regression linier dengan terlebih dahulu melakukan uji asumsi klasik.

\section{HASIL DAN PEMBAHASAN \\ Hasil \\ Uji Validitas}

Berdasarkan hasil pengolahan data didapatkan bahwa nilai Corrected Item-Total Colleration untuk masing-masing item variabel Faktor-faktor Yang Mempengaruhi Minat Mahasiswa Memilih Jurusan Kependidikan dan Non-Kependidikan seluruhnya lebih besar dari rtabel. Jika dapat dikatakan bahwa seluruh item pernyataan adalah valid.

Berdasarkan hasil pengolahan data didapatkan bahwa nilai Corrected Item-Total Colleration untuk masing-masing item variabel Minat Mahasiswa Memilih Jurusan Kependidikan dan Non-Kependidikan seluruhnya lebih besar dari rtabel. Jika dapat dikatakan bahwa seluruh item pernyataan adalah valid.

\section{Uji Reliabilitas}

Dari nilai cronbach's alpha dapat disimpulkan bahwa instrumen pertanyaan adalah reliabel karena memiliki nilai Cronbach's alpha lebih dari 0,6. Keandalan konsistensi antar item atau koefisien keandalan Cronbach's Alpha yaitu instrument variabel faktor-faktor yang Mempengaruhi Minat Mahasiswa sebesar 0,902. Untuk instrument Minat Mahasiswa memilih
NIAGAWAN Vol 7 No 2 Juli 2018

Jurusan Kependidikan dan Non Kependidikan sebesar 0,840. Data ini menunjukan nilai yang berada pada kisaran diatas 0,6. Dengan demikian semua instrument penelitian dapat dikatakan reliabel.

\section{ANALISIS HASIL DATA PENELITIAN \\ Faktor-Faktor yang Mempengaruhi Minat Mahasiswa Memilih Jurusan Kependidikan}

1. Tanggapan Responden Faktor Internal Yang Mempengaruhi Minat Mahasiswa Memilih Jurusan Kependidikan

Hasil dari perhitungan diatas, maka diperoleh persentase sebesar 69,5\%. Hal tersebut menunjukkan bahwa faktor internal yang mempengaruhi minat mahasiswa memilih jurusan Kependidikan masih tergolong kuat.

2. Tanggapan Responden Faktor Eksternal Yang Mempengaruhi Minat Mahasiswa Memilih Jurusan Kependidikan

Hasil dari perhitungan diatas, maka diperoleh persentase sebesar 65,6\%. Hal tersebut menunjukkan bahwa faktor eksternal yang mempengaruhi minat mahasiswa memilih jurusan Kependidikan masih tergolong kuat.

Faktor-Faktor yang Mempengaruhi Minat Mahasiswa Memilih Jurusan Non-

Kependidikan

1. Faktor Internal Yang Mempengaruhi Minat

Mahasiswa Memilih Jurusan Non-

Kependidikan

Hasil dari perhitungan diatas, maka diperoleh persentase sebesar 70,4\%. Hal tersebut menunjukkan bahwa faktor internal yang mempengaruhi minat mahasiswa memilih jurusan Non-Kependidikan masih tergolong kuat.

2. Faktor Eksternal Yang Mempengaruhi

Minat Mahasiswa Memilih Jurusan Non-

Kependidikan

Hasil dari perhitungan diatas, maka diperoleh persentase sebesar $68,8 \%$. Hal tersebut menunjukkan bahwa faktor eksternal yang mempengaruhi minat mahasiswa memilih Jurusan Non-Kependidikan masih tergolong kuat.

Faktor-faktor yang Mempengaruhi Minat Mahasiswa Dalam Memilih Jurusan

\section{Kependidikan}

Diperoleh suatu persamaan regresi berganda sebagai berikut.

$\grave{Y}=11,785+0,521 \mathrm{X} 1+0,491 \mathrm{X} 2$

Faktor-Faktor yang Mempengaruhi Minat Mahasiswa Dalam Memilih Jurusan NonKependidikan

Diperoleh suatu persamaan regresi berganda sebagai berikut.

$\grave{Y}=9,668+0,552 X 1+0,536 X 2$ 


\section{Pembahasan}

Berdasarkan hasil hipotesis pertama bahwa faktor internal berpengaruh positif dan signifikan terhadap minat belajar mahasiswa jurusan Kependidikan $69.5 \%$ dan dan non pendidikan $70 \%$ sisanya sekitar $30 \%$ dipengaruhi faktor internal lainnya yang tidak masuk dalam indikator penelitian, hipotesis kedua menunjukkan bahwa faktor eksternal berpengaruh positif dan signifikan terhadap minat pemilihan jurusan Kependidikan $65.6 \%$ dan non pendidikan $68.8 \%$ sisanya sekitar $35 \%$ dipengaruhi faktor eksternal lainnya yang tidak masuk dalam indikator penelitian, hasil hipotesis ketiga menunjukkan bahwa faktor internal dan eksternal secara simultan berpengaruh positif dan signifikan terhadap minat pemilihan jurusan Kependidikan dan Non-Kependidikan pada Mahasiswa Fakultas Ekonomi Angkatan 2014 pada jurusan Kependidikan 41,4\% dari minat pemilihan jurusan Kependidikan dipengaruhi oleh variabel faktor internal dan faktor eksternal mahasiswa Fakultas Ekonomi Universitas Negeri Medan, sedangkan 58,6\% dipengaruhi oleh faktor-faktor lain. Sedangkan NonKependidikan 20,4\% dari minat pemilihan jurusan Non-Kependidikan dipengaruhi oleh variabel faktor internal dan faktor eksternal, sedangkan $76 \%$ dipengaruhi oleh faktor-faktor lain, salah satunya adalah kecurangan masuk ke perguruan tinggi, Menurut seorang pengamat pendidikan dari Institut Penelitian Edukasi Abad 21, Xiong Bingqi, China tengah melanjutkan aksinya melawan pelaku kecurangan ujian.Menurut laporan berita Xinhua, pelajar yang diketahui melakukan kecurangan meski cuma sekali langsung dijebloskan ke penjara. Mereka terancam hukuman bui sampai tujuh tahun.Selain penjagaan saat ujian, distribusi soal di Beijing juga dijaga ketat dengan kemanan tingkat tinggi oleh Polisi SWAT. Media lokal memberitakan sekurangnya ada delapan anggota polisi SWAT menjaga tiap-tiap tempat ujian.Hal tersebut dilakukan untuk mencegah keberlanjutan adanya kecurangan.Selain itu ada juga kasus yang sama terjadi Delapan mahasiswa tertangkap basah melakukan perbuatan curang demi lolos masuk Fakultas Kedokteran Universitas Ahmad Dahlan (UAD) Yogyakarta. Kedelapan mahasiswa ini menggunakan alat komunikasi yang dirancang sedemikian rupa agar bisa berhubungan dengan pihak luar saat ujian berlangsung.

Kepala Biro Akademik dan Admisi UAD, Wahyu Widyaningsih, menjelaskan, alat yang digunakan kedelapan calon mahasiswa kedokteran tersebut tergolong canggih. Pihaknya menemukan dua buah aki, beberapa ponsel, delapan alat bantu dengar atau earpiece, tas, hingga jaket yang menjadi alat untuk melancarkan kecurangan tersebut.Modusnya dengan menanamkan chip di telinga. Chip tersebut cukup dalam dan hanya bisa diambil menggunakan magnet. Kedepannya universitas melakukan perketatan pengawasan, penggeledahan, cek fisik apa-apa yang tidak boleh dibawa ke lokasi ujian, dan tentunya masih banyak lagi faktor-faktor yang belum dijabarkan yang berpengaruh dan diharapkan adanya lanjutan untuk analisi penelitian ini kedepannya.

\section{KESIMPULAN DAN SARAN}

Berdasarkan pembahasan diatas dapat ditarik kesimpulan bahwa faktor yang mempengaruhi minat pemilihan jurusan pada mahasiswa Fakultas Ekonomi Universitas Negeri Medan adalah berasal dari faktor internal dibandingkan faktor eksternal seperti keinginan dari diri sendiri. Adapun saran pada penelitian ini kedepannya agar lebih melakukan pengujian awal mengenai minat dan bakat dari mahasiswa dalam pemilihan jurusan sehingga mahasiswa dalam menjalankan proses belajar mengajar didasarkan pada keinginan diri pribadi dibandingkan orang lain.

\section{REFERENSI}

Arikunto, Suharsimi. 2010. Prosedur Penelitian Suatu Pendekatan Praktik. Jakarta: Rineka Cipta.

Djamarah, Bahri, Syaiful. 2011. Metode Penelitian Pendidikan. Bandung: Alfabeta.

Hurlock, Elizabeth, B. 2010. Perkembangan Anak. Jakarta: Erlangga.

Khairani, Makmun. 2013. Psikologi Belajar. Yogyakarta: Aswaja Pressindo.

Usman, Moh, Uzer. 2012. Menjadi Guru Professional. Bandung: Remaja Rosdakarya Offset

Vivipermata. 2010. Apa itu Minat. http//vivipermata.blog.friendster.com. 12 Maret 2014

Kecurangan masuk perguruan Tinggi https://www.merdeka.com/dunia/banyakkecurangan-tim-swat-china-awasi-ujianmasuk-universitas.html dikutip 20 Sept 2018 
Kecurangan masuk perguruan Tinggi https://kumparan.com/@kumparannews/8 -calon-mahasiswa-pakai-alat-canggihuntuk-berbuat-curang-masuk-fk-uad27431110790556653 dikutip 20 Sept 2018

Widodo, HS, dan Kamal, M. (2011). Hubungan Minat Baca dengan Motivasi Memilih Studi Pendidikan Bahasa Indonesia, Sastra Indonesia dan Daerah Mahasiswa Tingkat I Universitas Negeri Malang Angkatan 2011. Jurnal Online Vokal Vol 1 No. 1 (2012) 